\title{
Aplikasi Mobile Mindfulness “Get Fresh And Rilexs” Dapat Menurunkan Stres Perawat
}

\section{Mindfulness Mobile Application "Get Fresh And Rilexs" Can Reduce Stress For Nurses}

\author{
Nunung Rachmawati ${ }^{1, *}$, Tenang Aristina ${ }^{2}$ \\ 1,2Akademi Keperawatan "YKY" Yogyakarta Jalan Patangpuluhan, Sonosewu, Ngestiharjo, Kasihan, \\ Bantul,Yogyakarta, Indonesia \\ 1 adan_wafa2000@yahoo.com*, ${ }^{2}$ tenangaristina@gmail.com \\ * corresponding author \\ Tanggal Submisi: 29 November 2020, Tanggal Penerimaan: 6 Februari 2021
}

\begin{abstract}
Abstrak
Penelitian bertujuan mengetahui pengaruh aplikasi mobile mindfulness "GFR" terhadap stres kerja perawat. Penelitian menggunakan pendekatan kuantitatif quasi eksperimen dengan rancangan pre dan post-test with control group design. Populasi penelitian adalah perawat unit khusus RSUD Sleman, dengan sampel perawat di unit HD dan IGD berjumlah 28. Instrumen yang digunakan yaitu DASS 42. Analisis data menggunakan Uji Mann Whitney. Hasil penelitian menunjukkan tidak terdapat perbedaan yang signifikan skor stres pada kelompok intervensi dan kontrol dengan nilai $\mathrm{p}>0,05$. Kesimpulan penelitian adalah tidak ada pengaruh signifikan penggunaan aplikasi mobile mindfulness "GFR" terhadap skor stres perawat di RSUD Sleman dengan nilai $\mathrm{p}=0,433$.
\end{abstract}

Kata kunci : aplikasi mobile; mindfulness; stres; perawat

\begin{abstract}
This study aims to determine the effect of the mindfulness mobile application "GFR" on nurses' work stress. The study used a quasi-experimental quantitative approach with a pre and post test design with a control group design. The study population was a special unit nurse in Sleman Hospital, with a sample of 28 nurses in the HD and IGD units. The instrument used was DASS 42. Data analysis used the Mann Whitney test. The result showed that there was no significant difference in stress scores in the intervention and control groups with a $p$ value $>0,05$. The conclusion of the study is thet there is no significant effect of using the mindfulness mobile application "GFR" on the stress score of nurse at the Sleman Hospital with a $\mathrm{p}$ value $=0,433$.
\end{abstract}

Keywords: mobile application; mindfulness; stress; nurses

\section{PENDAHULUAN}

Di dalam lingkungan kerja, terdapat stres kerja yaitu ketegangan yang sering dialami oleh karyawan yang dapat mengganggu situasi kerja serta konsentrasi dalam menyelesaikan tugas (Robert, 2010). Menurut data yang didapatkan oleh perusahaan layanan survei untuk perkembangan bisnis dan karier, hampir $73 \%$ pekerja di Amerika merasa stres saat bekerja. Menurut survei diperoleh data, paling tidak ada satu atau lebih masalah yang membuat seseorang merasa stres saat bekerja, $11 \%$ dari pekerja yang mengikuti survei ini mengungkapkan, gaji yang kecil merupakan masalah utama mereka. Selain gaji kecil, 
penyebab stres ini diikuti dengan adanya rekan kerja yang menjengkelkan (10\%), perjalanan ke kantor yang melelahkan (9\%), beban kerja yang tinggi (9\%), dan bekerja di perusahaan yang tidak sesuai dengan keinginan $(8 \%)$. Sedangkan penyebab stres lainnya juga diikuti oleh tidak adanya keseimbangan kerja dan kehidupan sosial (5\%), kurang kesempatan berkembang (5\%) dan bos yang menjengkelkan (4\%) (Harris, 2011).

Stres kerja banyak terjadi pada para pekerja di sektor kesehatan. Tanggung jawab terhadap manusia pada sektor kesehatan menyebabkan pekerja lebih rentan terhadap stres. Meskipun seluruh tenaga profesional di rumah sakit memiliki risiko stres, namun para perawat memiliki tingkat stres yang lebih tinggi (Yana, 2016). Perawat sebagai bagian penyedia layanan kesehatan di rumah sakit menghadapi banyak tuntutan dan tanggung jawab yang dapat menimbulkan stres dan kelelahan umum, khususnya saat menghadapi sistem kesehatan yang rumit terkait dengan kondisi pasien (Praissman, 2008). Apabila perawat mengalami stres kerja dan stres tersebut tidak dikelola dengan baik, maka akan membahayakan pasien (Yana, 2016). Menurut World Health Organization (WHO), jika sebagian besar perawat mengalami stres kerja, maka dapat mengganggu kinerja rumah sakit karena perawat tidak bisa memberikan pelayanan yang terbaik bagi rumah sakit dan pada akhirnya akan mempengaruhi daya saing mereka di pasar dan lebih dari itu bahkan dapat membahayakan kelangsungan organisasi rumah sakit.

Salah satu solusi yang mungkin adalah memperkenalkan perawat untuk praktek meditasi mindfulness. Mindfulness didemontrasikan untuk mempunyai manfaat profesional sebagai alat manajemen stres dan sebagai praktek perawatan diri yang memiliki potensi untuk mengubah respon terhadap stres (Luken \& Sammons, 2016). Intervensi manajemen stress berupa software atau teknologi dengan menggunakan bahasa indonesia dan mudah digunakan belum ada. Intervensi baru yang ditawarkan oleh peneliti untuk membantu perawat melakukan manajemen stres adalah penggunaan teknologi dengan memanfaatkan aplikasi android. Aplikasi ini disebut aplikasi mindfulness "Get Fresh and Rilexs". Aplikasi ini diharapkan dapat membantu perawat dalam melakukan manajemen stres secara mandiri yang dapat dilakukan perawat baik di rumah atau di rumah sakit. Tekhnik mindfulness STOP dimasukkan dalam menu panduan aplikasi ini yang dibuat dalam bentuk rekaman suara (audio) untuk memandu pemakai dalam menggunakan aplikasi ini. Program ini akan membantu perawat dalam melakukan manajemen stres secara mandiri yang dapat dilakukan kapanpun dan dimanapun.

Studi pendahuluan yang dilakukan oleh peneliti didapatkan informasi bahwa perawat yang berada di unit khusus seperti ICU, IGD, OK dan HD memiliki tingkat stres yang lebih tinggi dibandingkan dengan perawat yang berada di ruang rawat inap. Perawat di unit khusus memiliki beban dan tanggungjawab lebih dibandingkan perawat di ruang rawat inap, hal ini dikarenakan kondisi pasien yang di rawat di unit khusus dalam kondisi yang lebih berat dan memerlukan perhatian yang lebih dari perawat.

Penggunaan aplikasi android mindfulness yang disebut "Get Fresh and Rilexs" (GFR) ini diharapkan dapat menurunkan tingkat stres perawat khususnya perawat di unit khusus sehingga dapat meningkatkan pelayanan keperawatan yang diberikan. Penelitian ini dapat diaplikasikan oleh seluruh perawat untuk mengatasi stres kerja dan dapat dijadikan penelitian lanjutan mengenai adanya program aplikasi yang dapat digunakan dalam membantu tenaga kesehatan mengatasi masalah stres kerja.

\section{METODE PENELITIAN}

Penelitian ini menggunakan pendekatan kuantitatif quasi eksperimen dengan rancangan penelitian pre-test dan post-test with control group design, yaitu pendekatan yang digunakan untuk melihat pengaruh mindfulness application terhadap stres kerja perawat. Pada desain ini peneliti melakukan intervensi pada satu kelompok dengan pembanding. 
Instrumen dalam penelitian ini yaitu menggunakan Depression Anxiety Stress Scale 42 (Lovibond \& Lovibond, 1995). Dalam penelitian ini peneliti hanya memilih kuesioner yang mengukur tentang stres yaitu sejumlah 14 pertanyaan. Penelitian ini telah mendapatkan keterangan layak etik dari tempat penelitian yaitu KEPK RSUD Sleman yang berlaku selama kurun waktu tanggal 8 Mei 2019 sampai dengan tanggal 8 Mei 2020.

Populasi dalam penelitian ini adalah semua perawat yang berada di unit khusus RSUD Sleman. Sampel dalam penelitian ini adalah perawat di unit HD dan IGD RSUD Sleman yang berjumlah 28 perawat. Sejumlah 14 perawat di ruang IGD akan dijadikan kelompok kontrol dan sejumlah 14 perawat di ruang HD akan dijadikan kelompok intervensi, namun terdapat 2 perawat HD yang tidak diikutkan karena tidak sesuai dengan kriteria inklusi yaitu tidak memiliki Hp android. Pembagian kelompok dilakukan secara single blinded dimana subjek penelitian tidak mengetahui ke dalam kelompok mana subjek dikelompokkan dan hanya peneliti yang mengetahui. Kriteria inklusi dalam pemilihan sampel yaitu bersedia menjadi responden dan menandatangani informed consent, memiliki hp android. Kriteria eksklusi yaitu perawat yang akan mengambil cuti panjang.

Pengambilan data pada penelitian ini dilakukan selama tiga bulan dari bulan Juli sampai September 2019 di RSUD Sleman. Pada penelitian ini karakteristik perawat dilihat dengan membagikan lembar kuesioner yang wajib diisi oleh perawat baik kelompok kontrol maupun intervensi. Sedangkan skala stres perawat diukur dengan menggunakan lembar kuesioner DASS 42 yang diberikan kepada perawat baik kelompok kontrol maupun intervensi sebelum dan setelah diberikan perlakuan. Pada analisa data, karakteristik perawat dianalisis menggunakan frekuensi dan presentasi. Perbandingan skor stres sebelum dan sesudah penggunaan aplikasi mobile mindfulness "GFR" pada kelompok intervensi dan kontrol dinalisis menggunakan uji wilcoxon. Sedangkan perbedaan skor stres pada kelompok intervensi dan kontrol dianalisi menggunakan uji Mann Whitney.

\section{HASIL DAN PEMBAHASAN}

Data karakteristik demografi responden dijabarkan pada kelompok intervensi dan kontrol berdasarkan usia, jenis kelamin, agama, pendidikan, status dan pengalaman kerja. Data karakteristik responden menurut data demografi dapat dijelaskan sebagai berikut:

Tabel 1. Karakteristik Responden Perawat RSUD Sleman Yogyakarta

\begin{tabular}{|c|c|c|}
\hline \multirow{3}{*}{ Karakteristik } & \multicolumn{2}{|c|}{ Kelompok } \\
\hline & Intervensi & Kontrol \\
\hline & $(\mathrm{n}=12)$ & $(n=14)$ \\
\hline \multicolumn{3}{|l|}{ Usia } \\
\hline Mean & 36,4 & 40 \\
\hline Min-Max & $27-51$ & $23-55$ \\
\hline \multicolumn{3}{|l|}{ Jenis Kelamin (\%) } \\
\hline Laki-Laki & $33,3(\%)$ & $57,1(\%)$ \\
\hline Perempuan & $66,7(\%)$ & $42,9(\%)$ \\
\hline \multicolumn{3}{|l|}{ Agama (\%) } \\
\hline Islam & $100(\%)$ & $100(\%)$ \\
\hline \multicolumn{3}{|l|}{ Pendidikan (\%) } \\
\hline Diploma 3 Keperawatan & $591,7(\%)$ & $78,6(\%)$ \\
\hline
\end{tabular}




\begin{tabular}{lcc}
\hline S1 Keperawatan & $8,3(\%)$ & $14,3(\%)$ \\
\hline S2 Keperawatan & $0(\%)$ & $0(\%)$ \\
\hline Lain-lain & $0(\%)$ & $7,1(\%)$ \\
\hline Status (\%) & $91,7(\%)$ & $85,7(\%)$ \\
\hline Menikah & $8,3(\%)$ & $14,3(\%)$ \\
\hline Belum Menikah & & $14,3(\%)$ \\
\hline Pengalaman Kerja & $0(\%)$ & $0(\%)$ \\
\hline$<1$ tahun & $8,3(\%)$ & $85,7(\%)$ \\
\hline$>4$ tahun & $91,7(\%)$ &
\end{tabular}

Berdasar hasil penelitian yang telah dilakukan diketahui bahwa sebagian besar usia perawat pada kelompok intervensi berada di bawah rata-rata usia responden pada kelompok intervensi yaitu sebanyak 7 perawat $(58,3 \%)$. Rata-rata usia perawat di kelompok intervensi adalah 36,4. Sedangkan pada kelompok kontrol perawat yang berada dibawah dan di atas rata-rata usia responden pada kelompok kontrol sama yaitu 7 perawat $(50 \%)$ dengan ratarata usia yaitu 40. Pada penelitian ini terlihat rata-rata usia pada kelompok intervensi jauh lebih muda dibanding rata-rata usia pada kelompok kontrol. Umur memiliki hubungan yang bermakna dengan stres kerja pada pekerja. Semakin bertambah umur semakin rendah kondisi stres yang dialami, hal ini dikarenakan kelompok umur tersebut merupakan kelompok umur produktif yang dapat stabil dalam mengambil keputusan serta memiliki tanggungjawab sehingga bekerja secara bersungguh-sungguh (Nurani et al., 2017). Ratarata usia perawat yang lebih tua pada kelompok kontrol dibandingkan kelompok intervensi inilah yang mempengaruhi stres kerja sehingga skor stres maksimal sebelum perlakuan pada kelompok kontrol jauh lebih rendah.

Berdasarkan hasil penelitian yang telah dilakukan diketahui bahwa sebagian besar perawat baik pada kelompok intervensi maupun kontrol memiliki pengalaman di atas 4 tahun yaitu 11 perawat $(91,7 \%)$ pada kelompok intervensi dan 12 perawat $(85,7 \%)$ pada kelompok kontrol. Masa kerja memiliki hubungan yang bermakna dengan stres kerja pada pekerja (Nurani, Wahyuni \& Jayanti, 2017). Pengalaman dan pemahaman yang lebih lama akan membantu dalam mengatasi masalah (stresor) yang ditemukan dalam lingkunga kerja sehingga dapat digunakan sebagai upaya pencegahan stres (Utami et al., 2017).

Pada penelitian ini sebagian besar status perawat berstatus sudah menikah baik pada kelompok intervensi yaitu 11 perawat $(91,7 \%)$ maupun pada kelompok kontrol yaitu 12 perawat $(85,7 \%)$. Seseorang yang berstatus sudah menikah mempunyai tingkat stres lebih tinggi dibandingkan yang belum menikah (Rahmawati, 2008). Berdasarkan hasil penelitian yang telah dilakukan diketahui bahwa pendidikan terakhir pada perawat baik di kelompok intervensi maupun kontrol mayoritas adalah diploma 3 keperawatan yaitu sebesar 11 perawat $(91,7 \%)$ pada kelompok intervensi dan sebesar 11 perawat $(78,6)$ pada kelompok kontrol. Perawat dengan tingkat pendidikan diploma lebih mudah terpapar stres dibandingkan perawat dengan tingkat pendidikan yang lebih tinggi (Golubic et al., 2009).

Mindfulness merupakan salah satu tindakan keperawatan holistik non farmakologi untuk membantu dalam menurunkan stres maupun mengatasi masalah psikologis (Williams et al., 2015). Mindfulness membuat seseorang untuk fokus menyadari kondisi yang dihadapi saat ini, menerimanya dengan penuh keikhlasan, tanpa bereaksi dan memberikan penilaian pada momen ini (Dwidiyanti et al., 2018). Perkembangan teknologi telah membuat suatu intervensi berbasis internet yang menjadi pilihan cara untuk membantu mereka yang 
membutuhkan (Greer, 2015). Aplikasi mobile mindfulness "GFR" merupakan intervensi berbasis internet yang mudah digunakan dimanapun dan kapanpun untuk menurunkan tingkat stres.

Tabel 2. Gambaran Skor Stres Kelompok Intervensi (Perawat HD) dan Kelompok Kontrol (Perawat IGD) Sebelum dan Sesudah Penggunaan Aplikasi Mobile Mindfulness "GFR" $(\mathrm{n}=26)$

\begin{tabular}{ccccccc} 
Kelompok & Skor Stres & $\mathbf{N}$ & Mean & SD & Min & Max \\
\multirow{2}{*}{ Intervensi } & Sebelum & 12 & 7,00 & 5,045 & 0 & 16 \\
& Setelah & 12 & 3,92 & 3,825 & 1 & 13 \\
\multirow{2}{*}{ Kontrol } & Sebelum & 14 & 1,79 & 1,968 & 0 & 6 \\
& Setelah & 14 & 2,86 & 2,713 & 0 & 8
\end{tabular}

Berdasarkan hasil penelitian diketahui rata-rata skor stres perawat hemodialisa RSUD Sleman (kelompok intervensi) sebelum menggunaan aplikasi mobile mindfulness "GFR" yaitu sebesar 7,00 dengan skor minimal 0 dan skor maksimal 16. Skor stres sesudah menggunaan aplikasi mobile mindfulness "GFR" memiliki rata-rata sebesar 3,92 dengan skor minimal 1 dan skor maksimal 13. Sedangkan rata-rata skor stres perawat IGD RSUD Sleman (kelompok kontrol) sebelum yaitu sebesar 1,79 dengan skor minimal 0 dan skor maksimal 6. Skor stres sesudah memiliki rata-rata sebesar 2,86 dengan skor minimal 0 dan skor maksimal 8.

Gambaran skor stres perawat pada kelompok intervensi sebelum penggunaan aplikasi mobile mindfulness "GFR" di RSUD Sleman, diketahui bahwa sebelum penggunaan aplikasi mobile mindfulness "GFR" pada perawat memiliki skor minimal stres adalah 0 dan skor maksimal stres adalah 16. Sedangkan pada kelompok kontrol diketahui sebelumnya memiliki skor minimal stres 0 dan maksimal 6. Hasil tersebut menunjukkan bahwa tidak semua perawat mengalami stres baik di kelompok intervensi maupun kelompok kontrol. Skor maksimal stres perawat pada kelompok intervensi sebelum diberikan perlakuan jauh lebih tinggi yaitu 16 dibandingkan skor maksimal stres perawat pada kelompok kontrol yaitu 6. Pada penelitian ini jumlah perawat dengan jenis kelamin perempuan lebih banyak pada kelompok intervensi yaitu sejumlah 8 perawat $(66,7 \%)$ dibandingkan dengan jumlah perawat perempuan pada kelompok kontrol yaitu sejumlah 6 perawat $(42,9 \%)$. Penelitian yang dilakukan oleh University of Calgary in Alberta, Kanada pada tahun 2011 mengungkapkan bahwa penyebab stress dalam pekerjaan dipengaruhi oleh jenis kelamin. Dalam penelitian ini disebutkan bahwa perempuan lebih mudah terkena stres akibat kerja dari pada laki-laki. Menurut penelitian ini penyebab perempuan mengalami stres biasanya karena kurangnya penghargaan di tempat kerja, atau tidak dihargai atas upaya dan kerja keras yang dilakukannya (Harris, G, 2011).

Gambaran skor stres perawat pada kelompok intervensi setelah penggunaan aplikasi mobile mindfulness "GFR" di RSUD Sleman, diketahui bahwa setelah penggunaan aplikasi mobile mindfulness "GFR" pada perawat memiliki skor minimal stres adalah 1 dan skor maksimal stres adalah 13. Sedangkan pada kelompok kontrol diketahui setelahnya memiliki skor minimal stres 0 dan maksimal 8. Hasil di kelompok intervensi menunjukkan bahwa semua perawat menjadi mengalami stres, namun terdapat penurunan skor maksimal stres menjadi 13 yang semula skor maksimal stresnya 16. Sedangkan pada kelompok kontrol masih menunjukkan tidak semua perawat mengalami stres, namun terdapat kenaikan skor maksimal stres menjadi 8 yang semula skor maksimal stresnya 6. Skor maksimal stres yang mengalami peningkatan pada kelompok kontrol (perawat IGD) dapat dikarenakan beban kerja di ruangan yang fluktuatif. Hal ini disebabkan karena jumlah pasien dan tingkat 
keparahan pasien yang tidak dapat diprediksi, diharuskannya perawat untuk siap siaga selama 24 jam, diharuskannya perawat untuk dapat bekerja dengan cepat, tanggap dan tepat dalam menangani pasien serta adanya tekanan dan tuntutan untuk menyelamatkan pasien baik dari pimpinan rumah sakit maupun keluarga pasien (Mandasari et al., 2014).

Berdasarkan hasil penelitian diketahui bahwa sesudah penggunaan aplikasi mobile mindfulness "GFR" pada perawat HD (kelompok intervensi) memiliki skor minimal stres adalah 1 dan skor maksimal stres adalah 13. Hasil tersebut menunjukkan bahwa dari 12 perawat HD 8 diantaranya mengalami penurunan skor stres, 1 tidak mengalami peningkatan maupun penurunan, dan 3 diantaranya mengalami kenaikan skor stres. Perawat HD yang mengalami penurunan skor stres dikarenakan rasa tenang, rileks dan dapat menyadari kondisi yang sedang dialami saat ini. Penggunaan aplikasi mobile mindfulness dapat menurunkan tingkat stres (Park et al., 2017). Sebuah penelitian menunjukkan bahwa intervensi penurunan stres yang berbasis internet atau elektronik dapat menurunkan stres secara signifikan (Davies et al., 2014). Adanya aplikasi mobile mindfulness "GFR" ini memberikan kemudahan pada perawat HD untuk melakukan terapi keperawatan yang dapat dilakukan kapan saja dan dimana saja. Perawat HD (kelompok intervensi) yang tidak mengalami perubahan skor stres dapat terjadi karena banyak faktor yang mempengaruhi seperti kondisi pasien yang tidak dapat diprediksi atau tekanan dan tuntutan dari pasien atau keluarga pasien.

Tabel 3. Perbedaan Skor Stres Sebelum dan Setelah Penggunaan Aplikasi Mobile Mindfulness "GFR" pada kelompok Intervensi dan Kontrol di RSUD Sleman ( $\mathrm{n}=26)$

\begin{tabular}{ccccc}
\hline Skor Stres & Kelompok & $\mathbf{N}$ & Beda Mean & P Value \\
\hline Sebelum & Intervensi & 12 & 3,08 & 0,091 \\
\hline Setelah & Kontrol & 14 & $-1,07$ & 0,126 \\
\hline Setelah & & Kolum & & \\
\hline
\end{tabular}

*Uji Wilcoxon

Tabel 4. Perbedaan Skor Stres antara Kelompok Intervensi dan Kontrol Setelah Penggunaan Aplikasi Mobile Mindfulness "GFR" di RSUD Sleman ( $\mathrm{n}=26)$

\begin{tabular}{ccc}
\hline Skor Stres & N & P Value \\
\hline Kelompok Intervensi & 26 & 0,433 \\
\hline Kelompok Kontrol & 26 & \\
\hline
\end{tabular}

*Uji Mann-Whitney

Berdasarkan hasil penelitian menunjukkan nilai pada kelompok intervensi p Value 0,091 yang artinya nilainya $>0,05$. Nilai ini menunjukkan tidak ada perbedaan yang signifikan pada skor stres perawat sebelum dan setelah perlakuan pada kelompok intervensi yang berarti tidak adanya pengaruh penggunaan aplikasi mobile mindfulness "GFR" terhadap stres perawat. Demikian juga untuk kelompok kontrol memiliki p Value 0,126 sehingga nilainya $>0,05$. Hal ini berarti tidak ada perbedaan yang signifikan pada skor stres perawat sebelum dan setelah perlakuan pada kelompok kontrol. Berdasarkan hasil penelitian juga diketahui tidak terdapat perbedaan yang signifikan skor stres pada kelompok intervensi dengan kelompok kontrol dengan nilai $\mathrm{p}>0,05$. Pada penelitian ini dapat disimpulkan bahwa tidak ada pengaruh yang signifikan penggunaan aplikasi mobile mindfulness "GFR" terhadap skor stres perawat di RSUD Sleman dengan nilai $\mathrm{p}=0,433$.

Hasil penelitian tentang perbedaan skor stres perawat HD (kelompok intervensi) sebelum dan sesudah penggunaan aplikasi mobile mindfulness "GFR" di RSUD Sleman, didapatkan perbedaan penurunan rata-rata skor stres dari 7,00 menjadi 3,92 sehingga selisih rata-rata skor stres sebesar 3,08 dengan nilai $p$-value sebesar 0,091 ( $>>0,05)$. Sedangkan pada perawat IGD (kelompok kontrol) terdapat kenaikan rata-rata skor stres dari 1,79 
menjadi 2,86 sehingga selisih kenaikan sebesar 1,07 dengan nilai $p$-value 0,126 ( $p>0,05)$.

Berdasarkan hasil penelitian ini ditemukan bahwa penggunaan aplikasi mobile mindfulness "GFR" tidak memiliki pengaruh secara signifikan terhadap penurunan skor stres pada perawat HD. Namun dalam penelitian ini terdapat perubahan skor stres perawat sebelum dan sesudah penggunaan aplikasi mobile, dimana rata-rata skor stres perawat HD (kelompok intervensi) mengalami penurunan dan skor stres rata-rata perawat IGD (kelompok kontrol) mengalami kenaikan. Walaupun penggunaan aplikasi mobile mindfulness "GFR" ini tidak berpengaruh secara signifikan terhadap skor stres perawat tetapi tetap memberikan dampak positif bagi perubahan tingkat stres perawat HD. Berdasarkan hasil analisis skor stres dengan menggunakan uji wilcoxon, setelah penggunaan aplikasi mobile mindfulness "GFR" didapatkan penurunan rata-rata skor stres sebesar 3,08 dengan nilai $\mathrm{p}$ - value 0,091 ( $\mathrm{p}>0,05$ ), maka dapat disimpulkan bahwa tidak terdapat pengaruh yang signifikan penggunaan aplikasi mobile mindfulness "GFR" terhadap penurunan skor stres perawat.

Hasil penelitian ini berbeda dengan hasil beberapa penelitian yang membuktikan bahwa mindfulness mobile application dapat menurunkan tingkat stres (Park, et al, 2017). Ketidakkonsistenan ini dapat disebabkan oleh sesi atau waktu yang pendek dan kurangnya kontrol terhadap frekuensi penggunaan aplikasi (Lee \& Jung, 2018). Waktu penggunaan aplikasi mobile mindfulness "GFR" dalam penelitian ini selama 5 minggu dimana 1 minggu dilakukan pendampingan penggunaan aplikasi dan 4 minggu penggunaan aplikasi secara mandiri. Perawat HD (kelompok intervensi) menggunakan aplikasi secara mandiri sebanyak $1 \mathrm{kali} / \mathrm{hari}$ selama 4 minggu. Hal ini sudah sejalan dengan penelitian sebelumnya yang menunjukkan jangka waktu penggunaan aplikasi headspaces yaitu 30 hari yang dilakukan minimal 3 kali seminggu. Namun hasil dari penggunaan aplikasi headspaces tersebut dapat menurunkan stres pada mahasiswa (Yang et al., 2018). Penelitian lainnya juga menunjukkan bahwa peserta secara mandiri menjalani intervensi dengan menggunakan aplikasi mindfulness app selama 4 minggu dengan hasil penurunan tingkat stres yang dialami oleh mahasiswa (Siembor, 2017).

Kepatuhan peserta dalam penggunaan aplikasi dapat dilihat dari log aktivitas atau catatan aktivitas yang ada pada aplikasi. Dalam penelitian ini kepatuhan peserta dalam penggunaan aplikasi mobile mindfulness "GFR" masih kurang, hal ini dikarenakan kurangnya kontrol peneliti terhadap frekuensi penggunaan aplikasi. Selama penggunaan aplikasi secara mandiri selama 4 minggu oleh perawat HD, kontrol terhadap penggunaan aplikasi dilakukan oleh peneliti melalui ponsel dan tidak dilakukan secara langsung setiap hari. Perawat diminta untuk menyimpan riwayat latihan mindfulness kemudian di screenshoot dan dikirim ke peneliti untuk mengetahui kepatuhan pengguna. Peneliti juga melakukan kontrol secara langsung namun hanya dua kali saja. Kepatuhan peserta terhadap penggunaan aplikasi yang kurang ini seharusnya menjadi pertimbangan peneliti untuk menambahkan sesi atau waktu penggunaan aplikasi ini.

\section{SIMPULAN}

Terdapat perubahan skor stres perawat sebelum dan sesudah penggunaan aplikasi mobile mindfulness "GFR", dimana rata-rata skor stres perawat HD (kelompok intervensi) mengalami penurunan dan skor stres rata-rata perawat IGD (kelompok kontrol) mengalami kenaikan. Walaupun penggunaan aplikasi mobile mindfulness "GFR" ini tidak berpengaruh secara signifikan terhadap skor stres perawat tetapi tetap memberikan dampak positif bagi perubahan tingkat stres perawat HD. Skor stres perawat HD (kelompok intervensi) sebelum penggunaan aplikasi mobile mindfulness "GFR" di RSUD Sleman rata - rata sebesar 7,00 dan sesudah penggunaan rata- rata sebebsar 3,92. Sedangkan skor stres perawat IGD (kelompok kontrrol) sebelum penggunaan aplikasi pada kelompok intervensi rata-rata 
sebesar 1,79 dan sesudah rata-rata sebesar 2,86. Tidak terdapat pengaruh yang signifikan penggunaan aplikasi mobile mindfulness "GFR" terhadap skor stres kelompok intervensi dengan nilai $\mathrm{p}=0,091$ dan terhadap kelompok kontrol dengan nilai $\mathrm{p}=0,126$. Perawat sebaiknya menggunakan aplikasi mindfulness "GFR" ini secara rutin untuk membantu perawat meningkatkan koping stres sehingga stres kerja yang dialami perawat menurun. Peneliti lain dapat melanjutkan pengembangan aplikasi ini dan dibuat lebih menarik, serta dapat mengembangkan penggunaan aplikasi ini dari segi lama pemakaian dan jumlah responden penelitian.

\section{SARAN}

Bagi responden diharapkan dengan adanya Aplikasi Mobile Mindfulness "Get Fresh And Rilexs" dapat menurunkan stres perawat.

\section{REFERENCE}

Davies, E. B., Morriss, R., \& Glazebrook, C. (2014). Computer-delivered and web-based interventions to improve depression, anxiety, and psychological well-being of university students: a systematic review and meta-analysis. Journal of Medical Internet Research, $16(5)$.

Dwidiyanti, M., Pamungkas, A. Y. ., \& Ningsih, H. E. . (2018). Mindfulness caring pada stres. UNDIP Press.

Golubic, R., Milosevic, M., Knezevic, B., \& Mustajbegovic, J. (2009). Work-Related Stress, Education, And Work Ability Among Hospital Nurse. Journal of Advanced Nursing, 65(10), 2056-2066.

Greer, C. (2015). An online mindfulness intervention to reduce stress and anxiety among college students. Faculty of The University of Minnesota.

Harris, G, E. (2011). Individual Stress Management Coursework in Canadian Teacher Preparation Programs. Canadian Journal of Education, 34.

Lee, R. A., \& Jung, M. E. (2018). Evaluation of an mental health app DeStressify on university students mental health: Pilot trial. JMIR Mental Health, 5(1).

$\begin{array}{lllll}\text { Lovibond, } & \& & \text { Lovibond. } & \text { (1995). }\end{array}$ http://www.swim.edu.au/victims/resources/assersment/affect/DASS 42. Html

Luken, M., \& Sammons, A. (2016). Systematic Review of Mindfulness Practice for Reducing Job Burnout. The American Journal of Occupational Therapy, 70. https://doi.org/doi: 10.5014/ajot.2016.016956

Mandasari, T., Coiri, M., \& Sari, R. A. (2014). Analisis Beban Kerja Perawat UGD Menggunakan Maslach Burnout Inventory dan Modifikasi Heart. Jurnal Rekayasa Dan Manajemen Sistem Industri, 2(5), 1044-1054.

Nurani, P., Wahyuni, I., \& Jayanti, S. (2017). Faktor-Faktor yang Berhubungan dengan Stres Kerja pada Pekerja dengan Hazard Kimia di Dalam Ruang Terbatas di PT Z. Jurnal Kesehatan Masyarakat, 5(2), 136-146. https://ejournal3.undip.ac.id/index.php/jkm/article/view/16444/15844

Park, C. L., Riley, K. E., Braun, T. D., Jung, J. Y., Suh, H. G., Pescatello, L. S., \& Antoni, M. H. (2017). Yoga and Cognitive Behavioral Interventions to Reduce Stress in Incoming College Students: A Pilot Study. Journal of Applied Biobehavioral Research, 22(4), 125. https://onlinelibrary.wiley.com/doi/10.1111/jabr.12068

Praissman, S. (2008). Mindfulness-based stress reduction: A literature review and clinician's guide. Journal America Academi Nurse Practice, 20, 212-216. https://doi.org/http://doi.org/10.1111/j.1745-7599.2008.00306.x 
Rahmawati, S. (2008). Analisa Stres Kerja Karyawan pada PT. Bank Rakyat Indonesia (Persero) Tbk. Cabang Bogor. IPB, Bogor.

Robert, M. K. (2010). Theachers' Collective Efficacy, Job Satisfaction and Job Stress in Cross-Cultural Contest. The Journal of Experimental Education, 78(4).

Siembor, B. (2017). Exploring the effectiveness of a mindfulness training app for managing stress in a university student population: A pilot study.

Utami, P., Wahyuni, I., \& Ekawati. (2017). Faktor-Faktor yang Mempengaruhi Stres Kerja dan Pengendalian Stres Kerja pada Tenaga Kerja di Bagian Cargo PT Angkasa Pura Logistik Bandar Udara Internasional Ahmad Yani Semarang. Jurnal Kesehatan Masyarakat, 5(5), 311-317. http://ejournal3.undip.ac.id/index.php/jkm

Williams, H., Simmons, L. ., \& Tanabe, P. (2015). Mindfulness-based stress reduction in advanced nursing practice: A nonpharmacologic approach to health promotion,chronic disease management and symptom control. Journal Holistic Nurse, 20, 1-13.

Yana, D. (2016). Stres Kerja pada Perawat Instalasi Gawat Darurat di RSUD Pasar Rebo. Jurnal ARSI. www.journal.ui.ac.id

Yang, E., Schamber, E., Meyer, R. M. L., \& Gold, J. I. (2018). Happier Healers: Randomized controlled trial of mobile mindfulness for stress management. Journal of Alternative and Complementary Medicine, 00(00), 1-9. 